\title{
Comparison of pozzolanic activity of ilmenite MUD waste to other pozzolans used as an additive for concrete production
}

\author{
Jan Bobrowicz ${ }^{1}$ (D) . Filip Chyliński ${ }^{1}$
}

Received: 16 August 2018 / Accepted: 23 April 2020 / Published online: 11 May 2020

(c) The Author(s) 2020

\begin{abstract}
The article presents a comparison of pozzolanic activity of R-Mud, which is a by-product of $\mathrm{TiO}_{2}$, with known and long-used additives to cement and concrete. Tests were carried out comparing the amount of heat of the hydration of cement and cement with added R-Mud, silica fume, fly ash and trass. The reaction susceptibility of these additives with calcium hydroxide has also been studied using the thermogravimetric method. Results from this method have shown that the reactivity of R-Mud is high and at a similar level to silica fume, while it is much higher than the reactivity of fly ash or natural trass. The high level of pozzolanic reactivity of R-Mud has been confirmed by both isothermal calorimetry and thermogravimetry.
\end{abstract}

Keywords Hydration heat · Pozzolanic additives · Kinetics of heat development · Undissolved mud waste $\cdot$ Trass $\cdot$ Fly ash . Silica fume $\cdot$ Thermogravimetry $\cdot$ By-products

\section{Introduction}

Contemporary environmental concerns generate the need for such management of industrial waste that does not pose a potential threat and does not end up in landfill. The justification for this approach is that due to changes occurring in the processes of hydration of cement binders from waste components, it is often possible to obtain beneficial effects related to the formation of a microstructure similar to hydrated cement. The problem of usage of industrial waste still arouses interest, and further research is needed in this area.

The text describes the impact of R-Mud waste from the production of titanium dioxide on the hydration process of cement type CEM I 42.5 R compared to other well-known pozzolanic additives for concrete. The research was carried out using isothermal calorimetry and differential thermal analysis (DTA).

There are many examples of the use of waste for industrial purposes, but in this text we will limit ourselves to

Jan Bobrowicz

j.bobrowicz@itb.pl

Filip Chyliński

f.chylinski@itb.pl

1 Instytut Techniki Budowlanej, Warszawa ul. Filtrowa 1, Warsaw, Poland the most spectacular attempts related to the use of waste in concrete. A lot of research has been carried out on the disposal of waste containing heavy metals $[1,2]$, especially that which also contains large amounts of silica, which are used in the creation of the cement matrix microstructure. Many studies have been conducted on the use and optimisation of the transformation process in cement slurries of silica fume (SF) [3-5], fly ash (FA) [6-9] or natural pozzolana, namely trass $[10,11]$. R-Mud also has interesting pozzolanic properties, such as the concrete additives mentioned above. Of course, each of these industrial by-products is a valuable additive to concrete and/or cement. These additives react with calcium hydroxide formed in the hydration process of a cement binder to a different extent and after different amounts of time depending on their fineness, chemical composition and various reactions to $\mathrm{SiO}_{2}$. As a result of this reaction, hydrated calcium silicates $(\mathrm{C}-\mathrm{S}-\mathrm{H})$ form, which constitute the strength of the cement matrix $[12,13]$. They show significant differences in reactivity in the cement paste environment not only because of the different content of silica and the varying degrees of their activity but also other accompanying components found in industrial by-products or natural pozzolana. Additionally, the composition variation is accompanied by the differentiation of the grain size and form in which components have potential properties that can react with excess calcium hydroxide in the cement paste and, consequently, lead to the construction of the $\mathrm{C}-\mathrm{S}-\mathrm{H}$ 
phase $[14,15]$. The reaction of $\mathrm{SiO}_{2}$ with calcium hydroxide is much slower if the size of the grains of waste is bigger.

The calorimetric test method is often used to assess the compatibility of waste with the cement binder. It is advisable to monitor the progress of the hydration of cement binders, especially in the initial phase of the reaction with water, by means of calorimetry, because the result in the form of hydration speed or the amount of heat released answers many questions related to the interaction of the components of the test sample. This test illustrates the growth of the microstructure of the tested material, including many mixtures of binders and various types of additives [16, 17]. Additionally, a combination of calorimetric and differential thermal analysis results, which can be used to track chemical changes resulting in the formation of silicate phases responsible for building the microstructure of cement, gives much more information about the waste transformation process. From these studies, it is evident that the use of Portland cement additives, being a result of the interaction of mixed ingredients, produces very useful binders and gives new possibilities for their use in various types of concrete $[18,19]$.

The most commonly used include fly ash from the combustion of fuels, e.g. from black and brown coal, as well as waste from metallurgical production or other waste slag [20, 21], and silica fume. There have also been attempts to use waste from the production of titanium dioxide in construction $[22,23]$.

There is not a lot of information on the use of waste sludge from the process of titanium dioxide production in the creation of construction materials. A problem highlighted by some authors was the increased radioactivity of waste material, which was mainly dependent on the radioactivity of ilmenite deposits, which were the source of the raw material for the production of titanium dioxide [24, 25]. It has been suggested that the attempts made were partially limited by this high radioactivity, which for the waste itself can exceed the acceptable limits for construction products in many countries. With only small amounts of waste mud added, however, the finished products do not pose a threat and their natural radioactivity does not exceed the admissible thresholds.

The level of radioactivity and chemical composition depends on the origin of the raw material used in the production of titanium dioxide. The amounts of individual chemical compounds and minerals included in the waste mud from the production of $\mathrm{TiO}_{2}$, however, are controlled and known in the production process. The waste tested in this study did not show increased radioactivity. The initial analysis of the available post-decomposition mud suggested the possibility of using this waste in the process of cement and concrete production. This has been further discussed in our text from 2016 [26] and Llanes MC, González MJG, Moreno SMP, Raya JPB [27].
Table 1 Chemical composition (mass/\%) and physical properties of cement used for the study

\begin{tabular}{lll}
\hline No. & Characteristic & Value \\
\hline 1. & Beginning of setting time/min & 170 \\
2. & End of setting time $/ \mathrm{min}$ & 245 \\
3. & Relevant surface $/ \mathrm{cm}^{2} \mathrm{~g}^{-1}$ & 4060 \\
4. & $\mathrm{CaO} / \%$ & 64.42 \\
5. & $\mathrm{SiO}_{2} / \%$ & 20.06 \\
6. & $\mathrm{Al}_{2} \mathrm{O}_{3} / \%$ & 4.13 \\
7. & $\mathrm{Fe}_{2} \mathrm{O}_{3} / \%$ & 3.38 \\
8. & $\mathrm{MgO} / \%$ & 0.89 \\
9. & $\mathrm{SO}_{3} / \%$ & 3.11 \\
10. & $\mathrm{Na}_{2} \mathrm{O} / \%$ & 0.24 \\
11. & $\mathrm{K}_{2} \mathrm{O} / \%$ & 0.56 \\
12. & $\mathrm{Chlorides}_{\%} \%$ & 0.074 \\
15. & $\mathrm{Alkali}_{2} \mathrm{O}$ eq. $/ \%$ & 0.61 \\
\hline
\end{tabular}

Table 2 Phase composition (mass/\%) of cement used for the study

\begin{tabular}{llc}
\hline No. & Phase & Content/\% \\
\hline 1. & $\mathrm{C}_{3} \mathrm{~S}$ & 62.8 \\
2. & $\mathrm{C}_{2} \mathrm{~S}$ & 10.2 \\
3. & $\mathrm{C}_{3} \mathrm{~A}$ & 5.2 \\
4. & $\mathrm{C}_{4} \mathrm{AF}$ & 10.3 \\
\hline
\end{tabular}

Problems associated with waste which contains substantial quantities of reactive silica, such as post-decomposition mud from the production of titanium dioxide, are the subject of many studies [28-31]. Our research shows that this waste contains significant amounts of silica, which may contribute significantly to the process of building the microstructure of the hydraulic binder matrix, as suggested by earlier studies [32].

\section{Materials and method}

\section{Materials}

Cement CEM I 42.5R has been used in this research. Its chemical and phase composition is presented in Tables 1 and 2 .

The chemical composition of the materials used for the study (R-Mud, fly ash, silica fume and trass) is presented in Table 3. Raw material for $\mathrm{TiO}_{2}$ production indicated that the waste of R-Mud might contain significant amounts of silica, which in the production process may turn into colloidal silica, which, due to significant surface development, can have an impact on its reactivity. Confirmation of this fact was the aim of this study [26], as well as others currently in progress. In our experiment, we used rinsed 
Table 3 Concentration (mass/\%) of major elements in samples of waste (R-Mud, SF, trass, FA)

\begin{tabular}{|c|c|c|c|c|}
\hline \multirow[t]{2}{*}{ Elements } & \multicolumn{4}{|c|}{ Concentration/\% } \\
\hline & R-Mud & Silica fume & Trass & Fly ash \\
\hline $\mathrm{SiO}_{2}$ & 35.07 & 91.40 & 77.05 & 51.51 \\
\hline $\mathrm{TiO}_{2}$ & 33.05 & $<0.010$ & 0.090 & 1.086 \\
\hline $\mathrm{Al}_{2} \mathrm{O}_{3}$ & 5.53 & 0.15 & 12.35 & 25.71 \\
\hline $\mathrm{Fe}_{2} \mathrm{O}_{3}$ & 9.65 & 0.65 & 0.07 & 8.51 \\
\hline $\mathrm{MnO}$ & 0.532 & 0.058 & 0.012 & 0.096 \\
\hline $\mathrm{MgO}$ & 7.26 & 1.51 & 0.06 & 2.53 \\
\hline $\mathrm{CaO}$ & 3.09 & 0.09 & 0.30 & 3.82 \\
\hline $\mathrm{Na}_{2} \mathrm{O}$ & 1.10 & 1.02 & 3.25 & 1.37 \\
\hline $\mathrm{K}_{2} \mathrm{O}$ & 0.26 & 1.07 & 4.85 & 2.73 \\
\hline $\mathrm{P}_{2} \mathrm{O}_{5}$ & 0.012 & 0.125 & 0.015 & 0.312 \\
\hline$\left(\mathrm{SO}_{3}\right)$ & 0.05 & 0.01 & $<0.01$ & 0.48 \\
\hline (Cl) & 0.017 & 0.115 & 0.0110 & 0.015 \\
\hline (F) & $<0.01$ & $<0.01$ & 0.01 & $<0.01$ \\
\hline LOI & 3.9 & 3.80 & 1.20 & 1.37 \\
\hline SUM & 99.52 & 99.93 & 99.96 & 99.55 \\
\hline
\end{tabular}

Table 4 Specific surface area and density of materials used for testing

\begin{tabular}{lllll}
\hline Characteristic & R-Mud & Silica fume & Trass & Fly ash \\
\hline Relevant surface $/ \mathrm{cm}^{2} \mathrm{~g}^{-1}$ & 8390 & 23,160 & 6030 & 4020 \\
Density $/ \mathrm{g} \mathrm{cm}^{-3}$ & 3.15 & 2.20 & 2.56 & 2.22 \\
\hline
\end{tabular}

mud (R-Mud) in place of raw MUD, which is a factory byproduct. Mud was rinsed with water and filtrated. It was found that the leach contained some amounts of titanium sulphoxide, which is a very useful material for the production of titanium dioxide and, thus, it was returned to the production process. Rinsing mud with water decreased the content of sulphuric acid, which remains in it from production, from about $15 \%$ to less than $1 \%$. This operation enabled the use of R-MUD as an additive for concrete.

The surface area and density of tested materials are presented in Table 4.
In the performed calorimetric tests, mixtures containing cement CEM I 42.5 R were prepared, to which were added additives as a substitute of $15 \%$ of cement (R-Mud, silica fume, fly ash or trass).

\section{Calorimetric tests}

The process of testing the amount and rate of heat release has been carried out on cement paste as described in the samples in Table 4 . The test procedure was as follows:

- 8-gram samples (s) of cement and appropriate mixtures were placed in special calorimetric vessels

- 4 grams of water ( $w$ ) was placed in syringes

- After thermostatting was finished, the measurement was started, and the water was introduced through the injection needles into the measurement chambers

The calorimetric tests were carried out at a temperature of $20^{\circ} \mathrm{C}$ in a special measurement system on an isothermal calorimeter [33] for a minimum of $140 \mathrm{~h}$.

\section{Methodology of thermogravimetric tests}

The applied methodology of thermal analysis should illustrate the pozzolanic activity of selected types of waste by measuring how the content of calcium hydroxide changes over time.

Dry samples with composition described in Table 5 (columns 5-8) were mixed with water in the following mass proportions: 2 parts of pozzolanic material, 1 part calcium hydroxide, 2 parts water. Samples were stored in sealed containers (protected against water loss and $\mathrm{CO}_{2}$ access) at $20 \pm 2{ }^{\circ} \mathrm{C}$. Calcium hydroxide, analytical grade and demineralised water were used for the tests. The exception was silica fume, where the amount of water added was 3 parts. This was due to the necessity for good homogenisation of the mixture, in order to obtain a suitable consistency. All samples were prepared in a larger portion and divided into smaller, 10-gram samples for individual tests. All samples matured in identical conditions. Maturation was terminated

Table 5 Quantitative content of components used in the calorimetric (1-4) and thermogravimetric (5-8) studies

\begin{tabular}{|c|c|c|c|c|c|c|c|c|}
\hline $\begin{array}{l}\text { The content of the mixture compo- } \\
\text { nent in subsequent tests (mass/\%) }\end{array}$ & $\begin{array}{l}(\%) \\
\text { Sample } 1\end{array}$ & $\begin{array}{l}(\%) \\
\text { Sample } 2\end{array}$ & $\begin{array}{l}(\%) \\
\text { Sample } 3\end{array}$ & $\begin{array}{l}(\%) \\
\text { Sample } 4\end{array}$ & $\begin{array}{l}(\%) \\
\text { Sample } 5\end{array}$ & $\begin{array}{l}(\%) \\
\text { Sample } 6\end{array}$ & $\begin{array}{l}(\%) \\
\text { Sample } 7\end{array}$ & $\begin{array}{l}(\%) \\
\text { Sample } 8\end{array}$ \\
\hline Cement CEM I 42.5R (\%) & 85 & 85 & 85 & 85 & - & - & - & - \\
\hline Calcium hydroxide & - & - & - & - & 33.3 & 33.3 & 33.3 & 33.3 \\
\hline R-Mud & 15 & - & - & - & 66.6 & - & - & - \\
\hline Silica fume & - & 15 & - & - & - & 66.6 & - & - \\
\hline Trass & - & - & 15 & - & - & - & 66.6 & - \\
\hline Fly ash & - & - & - & 15 & - & - & - & 66.6 \\
\hline
\end{tabular}


at the determined point of reaction of the mixture components. The ripening process was stopped by pouring about $100 \mathrm{~g}$ of absolute ethanol (99.8\%) at the samples and stirring for about $1 \mathrm{~h}$, after which the solution was filtered. The dry residue was additionally dried in an oven at $40{ }^{\circ} \mathrm{C}$ for about $5 \mathrm{~min}$ in an air atmosphere. The dried sample was grinded and sieved through a sieve with a square mesh size of $0.063 \mathrm{~mm}$, averaged and then secured in a dry and sealed container until the thermographic examination. The DTA tests were carried out using the Thermal Analysis TA Instruments system SDT Q600.

Thermogravimetric measurements were conducted under the following conditions:

- Mass of sample: about $20 \mathrm{mg}$.

- Air gas flow: $100 \mathrm{~cm}^{3} \mathrm{~min}^{-1}$.

- Range of temperatures: $20-1000{ }^{\circ} \mathrm{C}$.

- Platinum crucibles.

- Temperature increase of $10{ }^{\circ} \mathrm{C} \mathrm{min}^{-1}$.

\section{Results}

The results of calorimetric tests are presented in Figs. 1-3. From the comparison of the total amount of heat released in the hydration process (Fig. 1) of cement mixtures CEM I 42.5R with individual pozzolanic additives, the smallest amount of heat released after $140 \mathrm{~h}$ was observed in silica fume. Although the waste R-Mud at the beginning of the hydration process (up to $0.2 \mathrm{~h}$ ) generates the greatest amount of heat, in this period the creation of the microstructure has not yet begun. This results from the properties of the tested waste $[26,27]$, which has been corroborated by the research conducted in this area by the authors of this article. It can be assumed that if we ignore

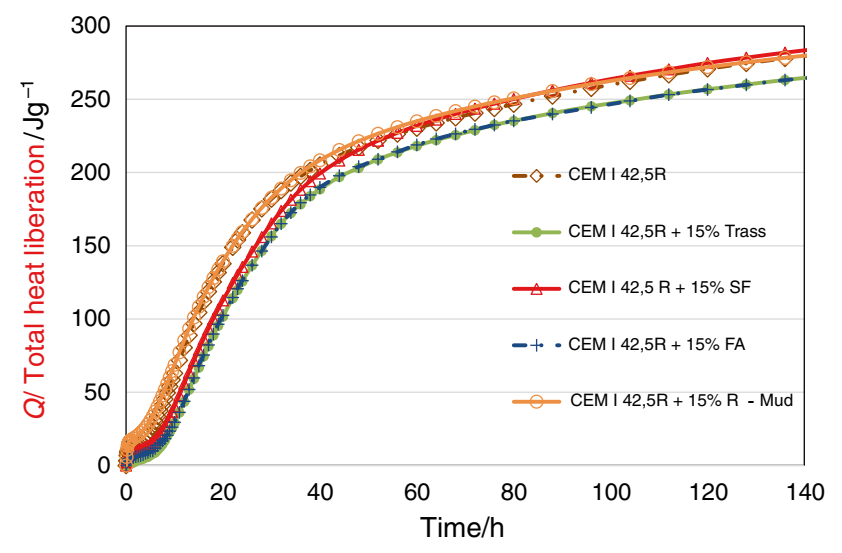

Fig. 1 Hydration heat $(Q)$ of cement, of tested mixtures of cement and individual pozzolana (see Table 5) at a temperature of $20{ }^{\circ} \mathrm{C}$ at $w / s=0.5$

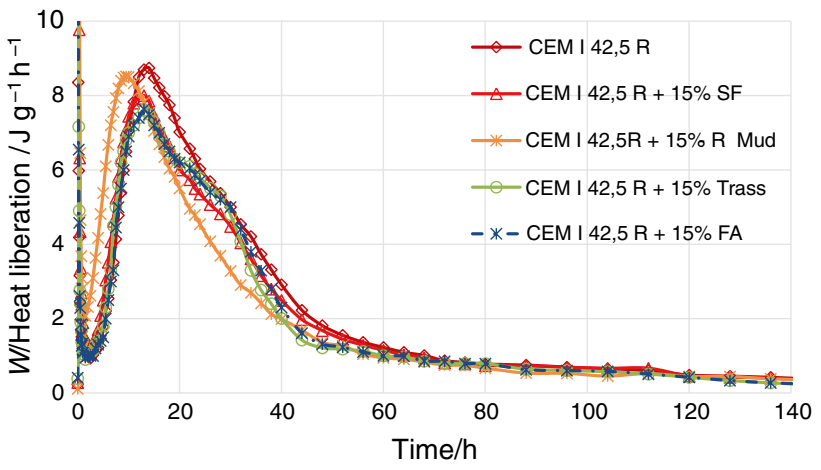

Fig. 2 Rate of heat development ( $W$ ) during hydration of cement, of tested mixtures of cement and individual pozzolana (see Table 5) at a temperature of $20^{\circ} \mathrm{C}$ at $w / s=0.5-W=\mathrm{d} Q / \mathrm{d} t\left(\mathrm{~J} \mathrm{~g}^{-1} \mathrm{~h}^{-1}\right)$

this effect at the beginning of the hydration process, then for this additive the result will be comparable in the initial period to the additive with silica fume and slightly more intense than for the additive containing trass or fly ash. The additions of fly ash and trass in calorimetric studies do not affect the level of hydration heat, and practically there are no differences in this respect over the duration of the experiment.

This is confirmed by the analysis presented in Fig. 3, which proves that R-Mud is not an inert addition, but actively participates in the process of cement hydration. The amount of heat generated is measured as the ratio of heat (I-Eq. 1), which is emitted during a defined period with a mixture of cement and $15 \%$ addition $\left(Q\left(t_{\mathrm{i}}\right)_{(\text {mix }}\right)$ to the heat generated during the hydration of cement in the same period $\left(Q\left(t_{\mathrm{i}}\right)_{(\mathrm{CEM})}\right)$. The level of hydration of the R-Mud additive and silica fume is comparable, while the fly ash and trass are slightly lower. These values indicate a significant participation of sludge in the hydration process in the first hours after introducing water to the mixture of binder and sludge.

The analysis shown in Fig. 3 can be described by formula:

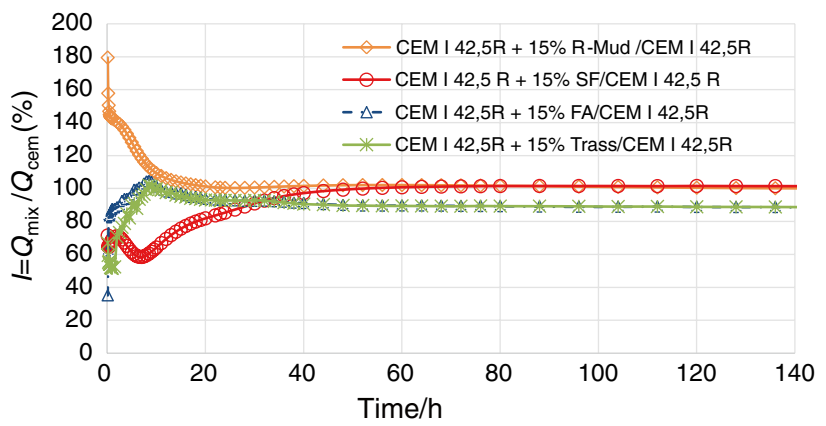

Fig. 3 Effect of 15\% (mass/\%) pozzolana addition on cement hydration level in relation to pure cement (I-formula 1) 


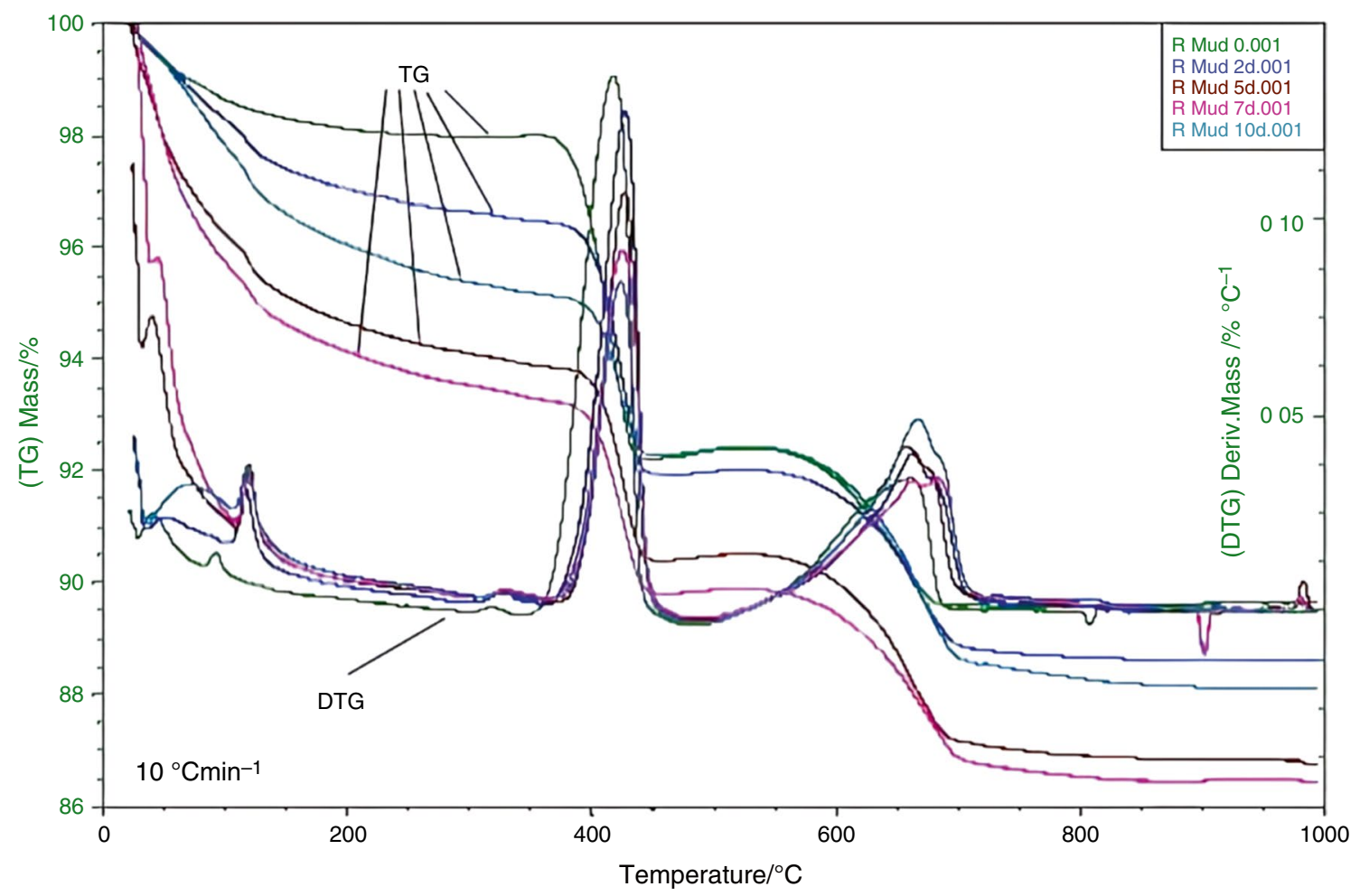

Fig. 4 Several selected results of the R-Mud transformation during the interaction of calcium hydroxide $\left(\mathrm{Ca}(\mathrm{OH})_{2}\right)$ in the period of $1-10$ days leading to the loss of hydroxide mass due to the reaction with $\mathrm{SiO}_{2}$ originating from R-Mud

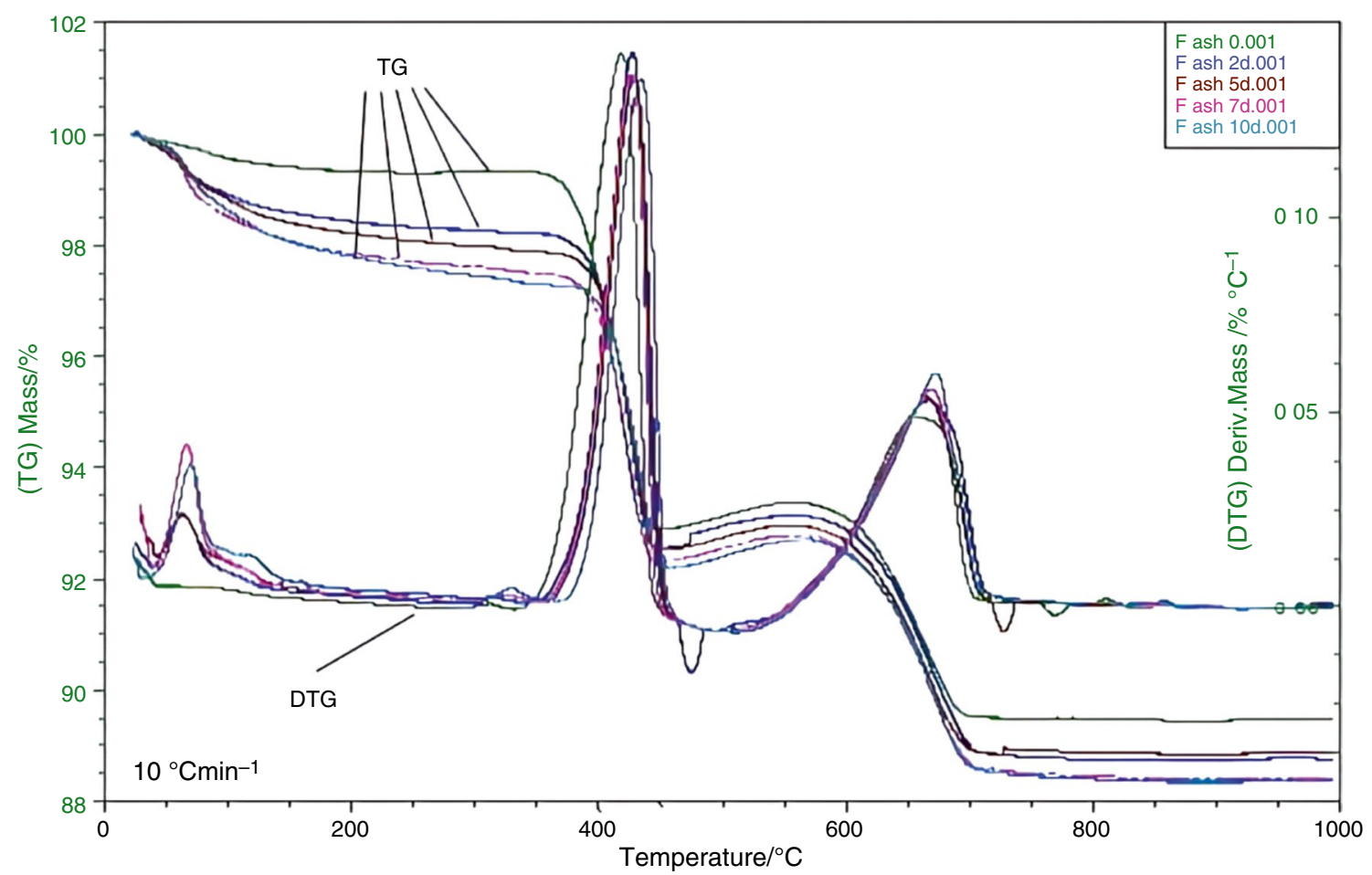

Fig. 5 Summary of several selected results of the fly ash transformation during the interaction of calcium hydroxide $\left(\mathrm{Ca}(\mathrm{OH})_{2}\right)$ in the period of 1-10 days leading to the loss of hydroxide mass due to the reaction with $\mathrm{SiO}_{2}$ coming from the ash 


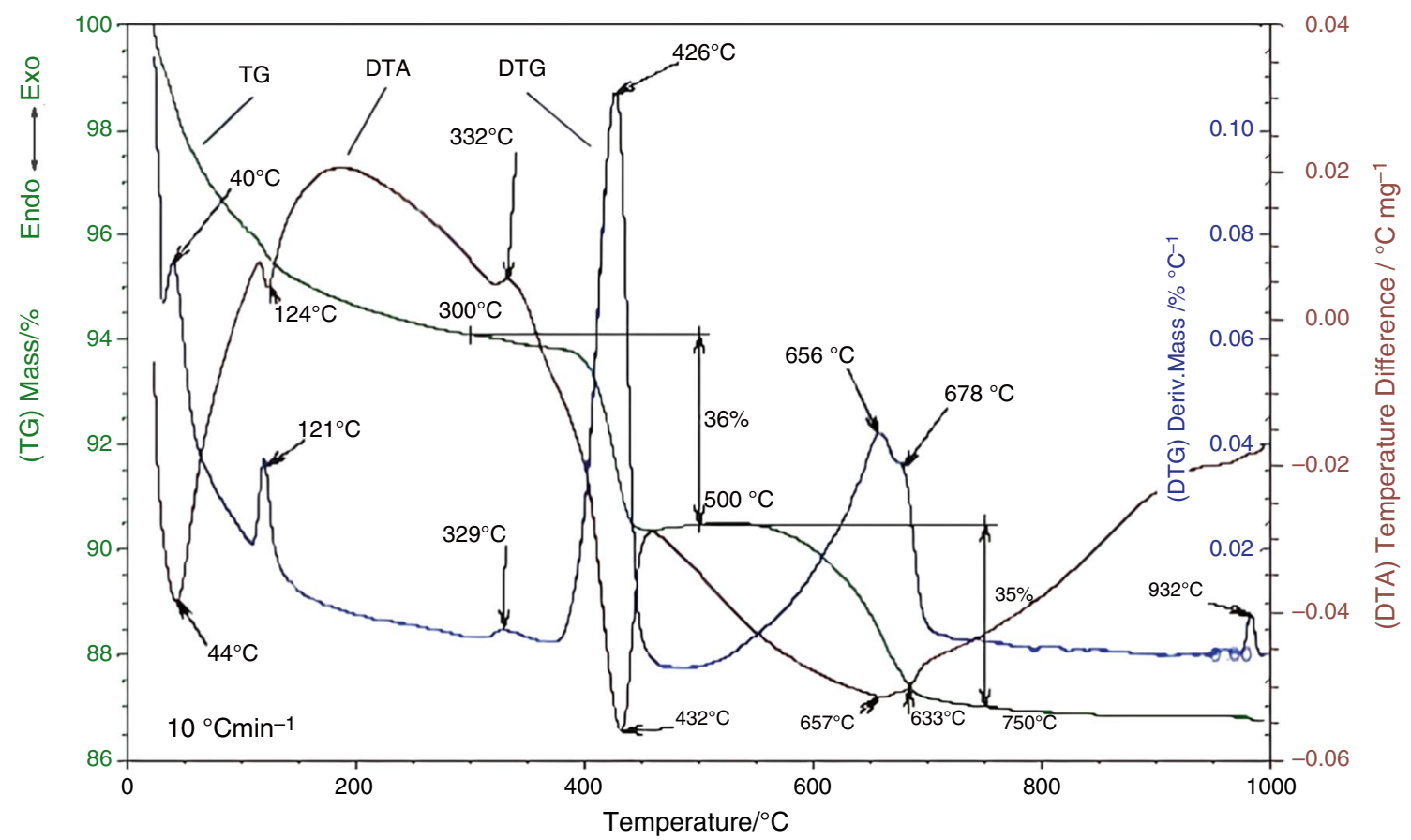

Fig. 6 Procedure for the analysis of individual R-Mud transformation results after the interaction of calcium hydroxide $\left(\mathrm{Ca}(\mathrm{OH})_{2}\right)$ in a period of 5 days, where the mass loss of hydroxide was determined on the basis of the reaction with $\mathrm{SiO}_{2}$ originating from the R-Mud

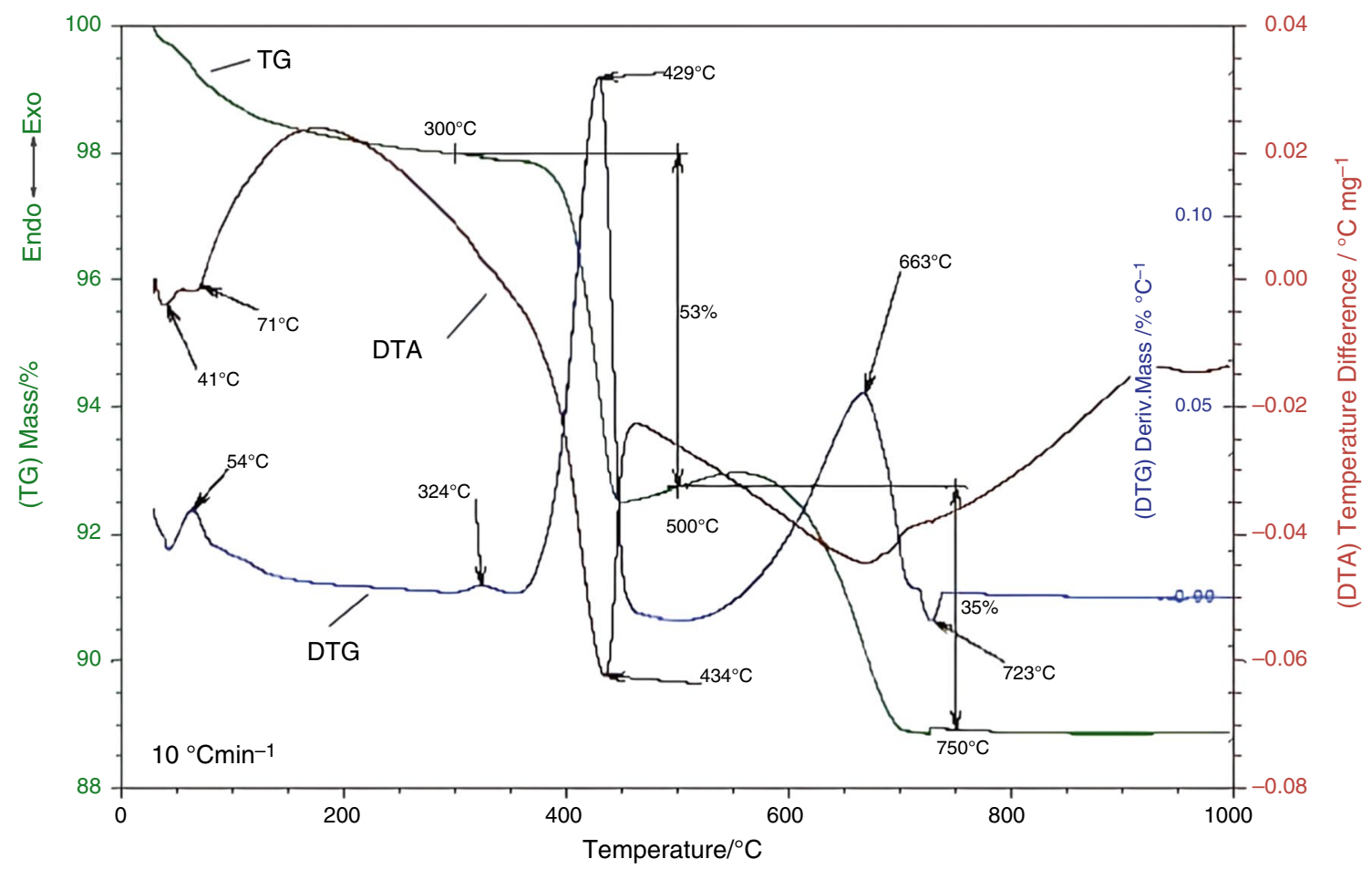

Fig. 7 Procedure for the analysis of individual fly ash transformation results after the interaction of calcium hydroxide $\left(\mathrm{Ca}(\mathrm{OH})_{2}\right)$ in a period of 5 days, where the mass loss of hydroxide was determined on the basis of the reaction with $\mathrm{SiO}_{2}$ originating from the fly ash 
Fig. 8 Transformation results of all tested pozzolana during the interaction of calcium hydroxide $\left(\mathrm{Ca}(\mathrm{OH})_{2}\right)$ in the period from 1-10 days leading to loss of hydroxide mass due to the reaction with $\mathrm{SiO}_{2}$

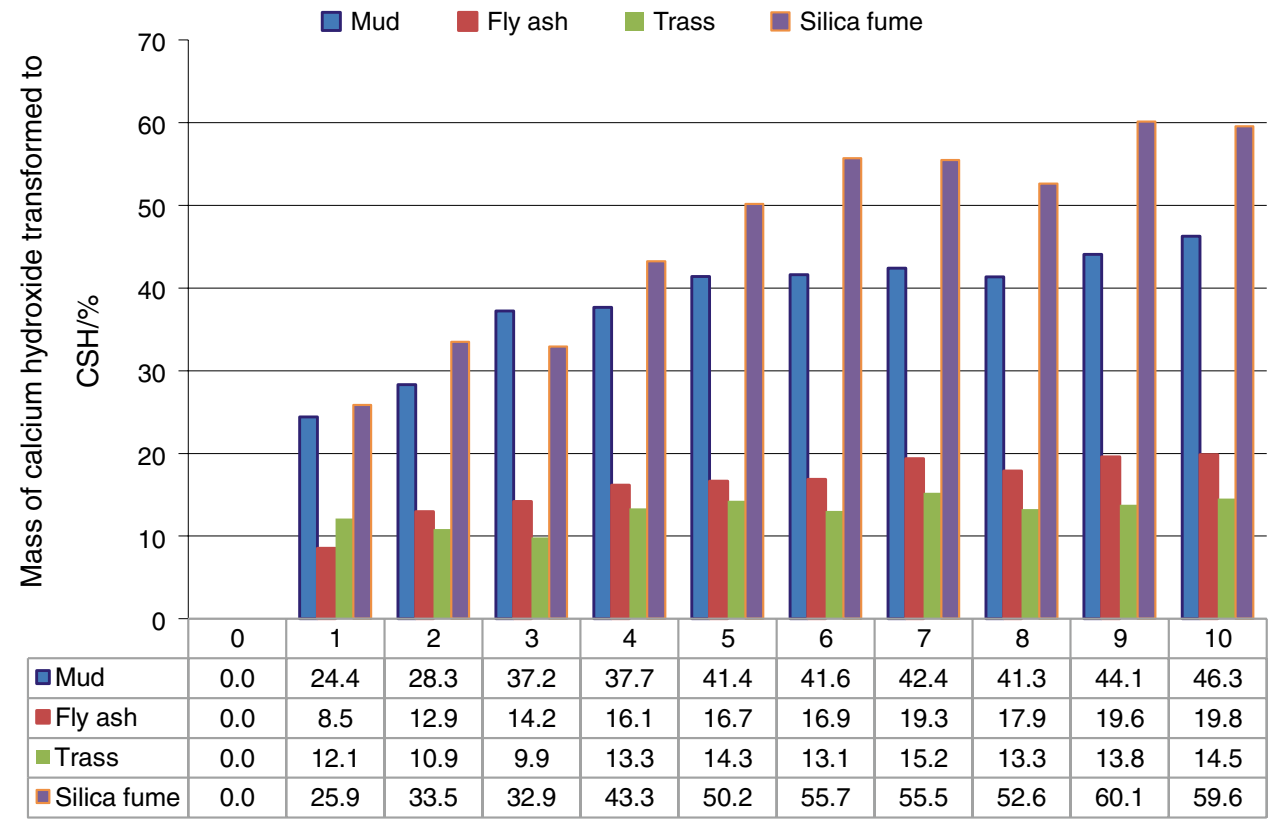

Age of samples/day
$I=\frac{Q\left(t_{\mathrm{i}}\right)(\mathrm{mix})}{Q\left(t_{\mathrm{i}}\right)(\mathrm{CEM})} \times 100$

where $Q\left(t_{\mathrm{i}}\right)_{(\mathrm{mix})}$-hydration heat of the mixture of additives and cement after time $t_{\mathrm{i}}$.

$Q\left(t_{\mathrm{i}}\right)_{(\mathrm{CEM})}$-hydration heat of cement after time.

Thermogravimetric tests carried out on samples as in Table 5, exposed to hydroxide at $20^{\circ} \mathrm{C}$ in a period from 1 to 10 days, were conducted for the same pozzolanic additives as in the case of calorimetry. Indicative results of these tests are shown in Figs. 4-7. All obtained results of derivatographic research are presented in Fig. 8.

These tests were carried out in order to compare the reactivity of individual pozzolana additives with calcium hydroxide. The objective of the comparison of the reaction capacity of the compact silica in the individual pozzolana was to compare the consumption rate of calcium hydroxide leading to the construction of the CSH phase, which is the basic material that creates the microstructure and determines the strength of the cement matrix. Also, the amount of calcium carbonate was measured. Calcium carbonate was created probably during the grinding and sieving operation because its amount did not depend on the time of curing the samples. The research aimed to show the possibility of using waste from the production of titanium dioxide (R-Mud) as a valuable additive to concrete. The results of thermogravimetric tests were compared with calorimetric tests to ascertain that the observed tendencies are true.

\section{Discussion and conclusion}

The results of tests showed that the reaction of R-Mud leading to the formation of the $\mathrm{CSH}$ phase is a relatively fast and effective process, as shown in Fig. 8. For example, the mass loss of calcium hydroxide after five days of reaction in contact with R-Mud represents $41.4 \%$, compared to $16.7 \%$ for fly ash and $14.3 \%$ for trass. In any case, the respective value for SF is $50.2 \%$, which is higher than R-Mud. All the results of derivatographic research presented in Fig. 8 confirm that the rate of calcium hydroxide loss is highest in the case of silica fume followed by R-Mud in the reaction environment, while the reactivity of fly ash and trass is much lower. This reactivity of hydroxide with concrete additives used in the concrete industry as a substitute for cement in comparison with R-Mud proves the possibility of using this waste as a reactive substitute for cement in concrete.

The high intensity of the reaction with calcium hydroxide is evident in both methods adopted to assess the reaction rate. From the very beginning, when R-Mud is added to the cement mixture, the level of heat emission determined calorimetrically, as well as the level of calcium hydroxide loss determined by the derivative method, indicates that the reactivity of this additive is high and slightly lower than that of silica fume (Fig. 8). The conducted experiments show that among the selected additives, in accordance with numerous publications [15, 21, 34-39] comparing FA, SF and trass with R-Mud, R-Mud is a very reactive additive for concrete 
or cement binders, not much less than SF. The comparison with trass and FA, however, favours R-Mud.

The observed high reactivity of R-Mud can be the effect of a high specific surface. Compared to SF, however, whose specific surface is higher, the activity of R-Mud is relatively higher than it would be only from surface development. The observed relatively high pozzolanic activity is also caused by very fine grains of colloidal silica, which are present in R-Mud.

The results of tests showed that R-Mud is highly effective in binding calcium hydroxide and creating the $\mathrm{CSH}$ phase. This characteristic makes it a potentially very valuable material as an additive to concrete instead of putting it in landfill as waste.

Open Access This article is licensed under a Creative Commons Attribution 4.0 International License, which permits use, sharing, adaptation, distribution and reproduction in any medium or format, as long as you give appropriate credit to the original author(s) and the source, provide a link to the Creative Commons licence, and indicate if changes were made. The images or other third party material in this article are included in the article's Creative Commons licence, unless indicated otherwise in a credit line to the material. If material is not included in the article's Creative Commons licence and your intended use is not permitted by statutory regulation or exceeds the permitted use, you will need to obtain permission directly from the copyright holder. To view a copy of this licence, visit http://creativecommons.org/licenses/by/4.0/.

\section{References}

1. Nocuń-Wczelik W. Calorimetry in the studies of cement-Pb compounds interaction. J Therm Anal Calorim. 2007;88:291-4.

2. Nocuń-Wczelik W, Małolepszy J. Application of calorimetry in studies of the immobilization of heavy metals in cementitious materials. Thermochim Acta. 1995;269-270:613-9.

3. Chen Y, Deng Y, Li M. Influence of Nano-SiO 2 on the consistency, setting time, early-age strength, and shrinkage of composite cement pastes. Berlin: Springer; 2016. p. 1-8.

4. Rahla KM, Mateus R, Bragança L. Comparative sustainability assessment of binary blended concretes using Supplementary Cementitious Materials (SCMs) and Ordinary Portland Cement (OPC). J Clean Prod. 2019;220:445-59.

5. Qing Y, Zenan Z, Deyu K, Rongshen C. Influence of nano-SiO2 addition on properties of hardened cement paste as compared with silica fume. Constr Build Mater. 2007;21:539-45.

6. Dittrich S, Neubauer J, Goetz-Neunhoeffer F. The influence of fly ash on the hydration of OPC within the first $44 \mathrm{~h}-$ a quantitative in situ XRD and heat flow calorimetry study. Cem Concr Res. 2014;56:129-38.

7. Bentz DP. Powder additions to mitigate retardation in high-volume fly ash mixtures. ACI Mater J. 2010;107:508-14.

8. Irbe L, Urbonas L, Heinz D. Coal fly ash activation-Comparison of isothermal calorimetric data and mortar strength. Thermochim Acta. 2018;659:151-6.

9. Han F, Zhang Z, Liu J, Yan P. Effect of water-to-binder ratio on the hydration kinetics of composite binder containing slag or fly ash. J Therm Anal Calorim. 2017;128:855-65.

10. Ercikdi B, Cihangir F, Kesimal A, Deveci H, Alp İ. Effect of natural pozzolans as mineral admixture on the performance of cemented-paste backfill of sulphide-rich tailings. Waste Manag Res. 2010;28(5):430-5.

11. Medina C, del Bosque SIF, Asensio E, Frías M, de Rojas SMI Mineralogy and microstructure of hydrated phases during the pozzolanic reaction in the sanitary ware waste $/ \mathrm{Ca}(\mathrm{OH}) 2$ system. J Am Ceram Soc. 2016;99:340-8.

12. Han F, Liu R, Wang D, Yan P. Characteristics of the hydration heat evolution of composite binder at different hydrating temperature. Thermochim Acta. 2014;586:52-7.

13. Pane I, Hansen W. Investigation of blended cement hydration by isothermal calorimetry and thermal analysis. Cem Concr Res. 2005;35:1155-64.

14. Kurdowski W. The problem of compatibility of admixture with cement, another approach. Cem Wapno Bet. 2010;5:296-305.

15. Kurdowski W. Cement and concrete chemistry. Dordrecht: Springer; 2014.

16. Lura P, Winnefeld F, Klemm S. Simultaneous measurements of heat of hydration and chemical shrinkage on hardening cement pastes. J Therm Anal Calorim. 2010;101:925-32.

17. Lothenbach B, Zajac M. Application of thermodynamic modelling to hydrated cements. New York: Elsevier; 2019.

18. Pacewska B, Wilińska I, Bukowska M, Blonkowski G, NocuńWczelik W. An attempt to improve the pozzolanic activity of waste aluminosilicate catalyst. J Therm Anal Calorim. 2004;77:133-42.

19. Nocuń-Wczelik W, Bochenek A, Migdał M. Calorimetry and other methods in the studies of expansive cement hydrating mixtures. $\mathrm{J}$ Therm Anal Calorim. 2012;109:529-35.

20. Pacewska B, Wilińska I, Bukowska M, Nocuń-Wczelik W. Effect of waste aluminosilicate material on cement hydration and properties of cement mortars. Cem Concr Res. 2002;32:1823-30.

21. Nocuń-Wczelik W. Heat evolution in alkali activated synthetic slag-metakaolin mixtures. J Therm Anal Calorim. 2006;86:739-43.

22. Puertas F, García-Díaz I, Palacios M, Gazulla MF, Gómez MP, Orduña M. Clinkers and cements obtained from raw mix containing ceramic waste as a raw material. Characterization, hydration and leaching studies. Cem Concr Compos. 2010;32:175-86.

23. Contreras M, Gázquez MJ, García-Díaz I, Alguacil FJ, López FA, Bolívar JP. Valorisation of waste ilmenite mud in the manufacture of sulphur polymer cement. J Environ Manag. 2013;128:625-30.

24. Gázquez MJ, Mantero J, Bolívar JP, García-Tenorio R, Vaca F, Lozano RL. Physico-chemical and radioactive characterization of $\mathrm{TiO} 2$ undissolved mud for its valorization. J Hazard Mater. 2011;191:269-76.

25. Contreras M, Martín MI, Gázquez MJ, Romero M, Bolívar JP. Valorisation of ilmenite mud waste in the manufacture of commercial ceramic. Constr Build Mater. 2014;72:31-40.

26. Bobrowicz J, Chyliński F. The influence of ilmenite mud waste on the hydration process of Portland cement. J Therm Anal Calorim. 2016;126:493-8.

27. Llanes MC, González MJG, Moreno SMP, Raya JPB. Recovery of ilmenite mud as an additive in commercial Portland cements. Environ Sci Pollut Res. 2018;25:24695-703.

28. Wilińska I, Pacewska B. Influence of selected activating methods on hydration processes of mixtures containing high and very high amount of fly ash. J Therm Anal Calorim. 2018;133:823-43.

29. Snelson DG, Wild S, O'Farrell M. Heat of hydration of Portland Cement-Metakaolin-Fly ash (PC-MK-PFA) blends. Cem Concr Res. 2008;38:832-40.

30. Pane I, Hansen W. Investigation on key properties controlling early-age stress development of blended cement concrete. Cem Concr Res. 2008;38:1325-35.

31. Mostafa NY, Brown PW. Heat of hydration of high reactive pozzolans in blended cements: isothermal conduction calorimetry. Thermochim Acta. 2005;435:162-7. 
32. Xu Z, Zhou Z, Du P, Cheng X. Effects of nano-limestone on hydration properties of tricalcium silicate. J Therm Anal Calorim. 2017;129:75-83.

33. Witakowski P, Czamarska D, Bobrowicz J. Skoputeryzowany układ do pomiarów kalorymetrycznych Część I Aparatura. Cem Waspno Gips. 1991;7:182-6 (in Polish).

34. Elżbieta Horoszczaruk. Role of nanosilica in the formation of the properties of cement composites, state of the art. Cem Wapno Bet. 2018;6:487-95.

35. Mertens G, Snellings R, Van Balen K, Bicer-Simsir B, Verlooy $\mathrm{P}$, Elsen J. Pozzolanic reactions of common natural zeolites with lime and parameters affecting their reactivity. Cem Concr Res. 2009;39:233-40.

36. Ramezanianpour AA. The role of supplementary cementing materials on sustainable development. Cement Replacement Materials., Springer Geochemistry/MineralogyBerlin: Springer; 2014.
37. Roszczynialski W. Determination of pozzolanic activity of materials by thermal analysis. J Therm Anal Calorim. 2002;70:387-92.

38. Li X, Snellings R, Antoni M, Alderete NM, Ben Haha M, Bishnoi $S$, et al. Reactivity tests for supplementary cementitious materials: RILEM TC 267-TRM phase 1. Mater Struct. 2018;51:151.

39. Nasr D, Behforouz B, Borujeni PR, Borujeni SA, Zehtab B. Effect of nano-silica on mechanical properties and durability of self-compacting mortar containing natural zeolite: experimental investigations and artificial neural network modeling. Constr Build Mater. 2019;229:116888.

Publisher's Note Springer Nature remains neutral with regard to jurisdictional claims in published maps and institutional affiliations. 